letter, reading proficiency and reading habits would be achieved more easily. This study examines this hypothesis against experience at home and abroad, and follows this up with objective testing in experimental situations. The decisive conclusions should form an invaluable aid to teachers, administrators and all concerned with progress in education.

\section{Foot-and-Mouth Disease in Madras}

IN the combined report of the King Institute of Preventive Medicine, Guindy, and the Government Analyst, Madras, for the year 1957-58, information is provided about the problem of foot-and-mouth disease in Madras State (Report of the King Institute of Preventive Medicine, Guindy, and Report of the Government Analyst. Madras, for the period from 1st April, 1957, to slst March, 1958. Pp. i+121. Guindy, Madras : King Institute of Preventive Medicine, 1960). The conclusions of a committee set up to examine the position were that : foot-andmouth disease is endemic in the whole Madras State and occurs year after year; the carrier state of the infected animals is quite long and lasts a year ; it is not practicable to select virus-free animals for vaccination; and that with the facilities available at the Institute, every possible precaution has been taken to minimize the infection and ite spread. The committee was of the opinion that controlled measures have become all the more important, as prophylactic vaccines against foot-and-mouth disease are not available in India. It is also not practicable to import vaccines from abroad as they are very costly and protection against local strains cannot be assured. The report contains detailed information about all measures taken to safeguard public health in the State.

\section{A New Frcg from Brazil}

AMONG the specimens in a small collection of frogs sent to Coleman J. Goin of the University of Florida was a single individual of a striking little Hyla. It has been named Hyla bokermanni, n. sp. The specimen was an adult female and has small rounded vomerine tooth patches and small rounded dorsolateral stripes on a chocolate-brown background. It is perhaps most closely allied to $H$. parviceps, from which it differs in its smaller size, shorter legs, smoother skin, and in having a pattern of dorsolateral stripes as well as differences in detail of pattern of the thighs. From $H$. microps, which may also be a near relative, it likewise differs in its small size, shorter legs and in the pattern of dorsolateral stripes ( $A n n$. Mag. Nat. Hist., 2, No. 24 ; December 1959).

Fecundity of the Nile Mormyrid, Hyperopisus bebe (Lacepede)

ATtention has recently been directed to the importance of the fish fauna of the Nile as a valuable source of protein food. Experimental stations have been constructed for the breeding of some of the economically important species of the Nile fishes. Work on the fecundity of the Nile fishes would, therefore, be of importance for such projects and for a general control scheme for the maintenance and increase of the productivity of the rivers, but except for the observations made by Kenchington in 1933 on the fecundity of the Nile perch Lates niloticus (Linnæus 1762) no one has previously examined this problem. G. Nawar has now investigated the fecundity of Hyperopisus bebe (Lacepede) (Ann. Mag. Nat. Hist., 2, No. 22; October 1959). The fecundity, de- fined as the number of eggs produced by the female during the breeding season, was determined through the study of 62 females. It was found to vary in the range $2,030-33,060$, provided that the fecundity is calculated on the basis of counting the whole number of ova per ovary. A correlation between fecundity, length and weight of the specimen was observed.

\section{New Virus isolated from Culicine Mosquitoes}

During April 1958, an outbreak of febrile illness of unknown ætiology occurred among the residents of Germiston, a town near Johannesburg. As it was considered that this outbreak might have been due to an arthropod-borne virus, mosquitoes were collected with the intention of isolating the causal agent. In the centre of Germiston, which is a highly industrialized town, is a small lake with an adjoining golf course and park. On the edge of the lake is a dense reed-bed with a heronry in which large numbers of cattle egrets (Bubulcus ibis) roost and breed. At the time the mosquito collections were made, the heronry contained hundreds of fledgling cattle egrets. Associated with the reeds and surrounding trees were lesser numbers of black-headed herons, sacred ibises, coots, moorhens, reed warblers, weavers and doves. Mosquitoes were collected on the edge of the lake in proximity to the reods. From Culex (Neoculex) rubinotus Theobald mosquitoes collected at Germiston, three virus strains were isolated. Two of these strains were identical and have been shown to belong to the Bunyamwera group of arthropod-borne viruses. B. M. MeIntosh, R. H. Kokernot and H. E. Paterson report in the April issue of the South African Journal of Medical Science that they have now isolated a third virus strain which has been shown to be unrelated immunologically to many arthropod-borne viruses. Accordingly, the name Witwatersrand virus has been proposed, which has reference to the geographical area where the mosquitoes were collected and from which the agent was isolated.

\section{Essay Competition on Corrosion Science}

THE Corrosion Group of the Society of Chemical Industry is organizing a competition designed to encourage persons who are still in the early stages of their career to take an interest in corrosion science. The competition will take the form of an essay, and persons aged not more than 30 years are invited to present an essay or paper on any aspect of corrosion of metals and its prevention. A prize of 25 guineas will be awarded. The closing date for receipt of entries is March 31, which should be addressed to Corrosion Group Essay Competition, c/o Society of Chemical Industry, 14 Belgrave Square, London, S.W.1, whence further information can be obtained.

"Effect of Corona Discharges on Po!yethylene"

REFERRING to the communication under this title published in Nature of November 12, 1960, p. 577, Mr. L. R. Hougen states : "Further work has revealed that the identification of the alcohols in the gas chromatogram (Fig. 1) is incorrect, due to false labelling of the marker compounds, which was beyond my control. A correct interpretation of the gas chromatogram indicates that the distribution of breakdown products between the different carbon numbers is statistical, and that the largest peak represents $\mathrm{C}_{20}$ secondary alcohols, which suggest that a free-radical mechanism may play an active part in the breakdown reactions". 